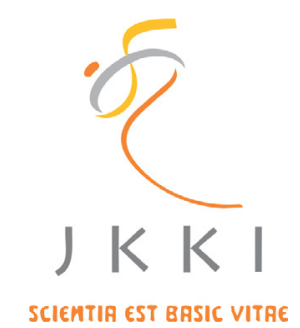

Jurnal Kedokteran dan Kesehatan Indonesia

Indonesian Journal of Medicine and Health

Journal homepage : https://journal.uii.ac.id/JKKI

\title{
Achievement of universal health coverage in Surakarta city: policy analysis
}

Rizky Amalia Puspitaningrum*1, Ari Probandari², Eti Poncorini Pamungkasari², Tonang Dwi Ardyanto ${ }^{3,4}$, Ema Nur Fitriana ${ }^{1}$

${ }^{1}$ Master Program of Family Medicine, Universitas Sebelas Maret, Surakarta, Indonesia

${ }^{2}$ Department of Public Health, Faculty of Medicine, Universitas Sebelas Maret, Surakarta, Indonesia

${ }^{3}$ Department of Clinical Pathology, Faculty of Medicine, Universitas Sebelas Maret, Surakarta, Indonesia

${ }^{4}$ Sebelas Maret University Hospital, Surakarta, Indonesia

Original Article

\begin{tabular}{l}
\hline ART I L E I NF O \\
\hline Keywords: \\
Health Insurance, \\
Health Coverage, \\
City of Surakarta, \\
Policy Analysis Triangle \\
*Corresponding author: \\
rizkyap191@@gmail.com \\
\hline DoI: 10.20885/JKKI.Vol10.Iss2.art7 \\
\hline History: \\
Received: May 3, 2019 \\
Accepted: July 16, 2019 \\
Online: August 30, 2016 \\
\hline
\end{tabular}

Copyright @2019 Authors. This is an open access article distributed under the terms of the Creative Commons Attribution-NonCommercial $\quad 4.0$ International Licence (http:// creativecommons.org/licences/ by-nc/4.0/).

\section{ABSTRACT}

Background: Jaminan Kesehatan Nasional (JKN) is the health policy of the Indonesian government to achieve Universal Health Coverage (UHC), where each City or District has a varied regional policy in implementing it. Surakarta City is one of the regions that has been able to reach UHC. Policy analysis triangle is used to understand the various factors involved in each policy process.

Objective: This study aims to explore deeply the implementation of JKN policy in Surakarta City to be able to achieve UHC based on a policy analysis triangle.

Methods: This type of research is a qualitative study with a case study approach. The study was conducted in Surakarta City, Central Java, from September 2018 to March 2019. Data collection was carried out through in-depth interviews and document analysis. Sampling technique with criterion sampling. The research informants were five people who were the leaders of the Surakarta City Government, and 10 people from the Surakarta City community. Data validity was done by triangulation, member check, and peer debriefing.

Results: The implementation of JKN policy in the city of Surakarta to reach UHC was influenced by: actors who were highly committed and competent in the success of the JKN program, a dynamic process in adjusting central policy to the regions by implementing various strategies and innovations to increase JKN membership coverage; political factors with policy making that support the achievement of UHC, environmental factors where population density in Surakarta City is the most densely populated in Central Java, there is a high awareness and willingness of the people of Surakarta City to have JKN, and technological support that facilitates JKN coordination and implementation.

Conclusion: Achieving UHC in Surakarta City is the result of optimizing the four factors in the triangle analysis policy.

Latar Belakang: Jaminan Kesehatan Nasional (JKN) merupakan kebijakan kesehatan pemerintah Indonesia untuk mencapai Universal Health Coverage (UHC), di mana setiap Kota atau Kabupaten memiliki kebijakan daerah yang bervariasi dalam mengimplementasikannya. Kota Surakarta merupakan salah satu daerah yang telah mampu meraih UHC. Policy analysis triangle digunakan untuk memahami berbagai faktor yang terkait dalam setiap proses kebijakan. 
Tujuan: Penelitian ini bertujuan untuk mengeksplorasi secara mendalam mengenai implementasi kebijakan JKN di Kota Surakarta hingga mampu meraih UHC berdasarkan policy analysis triangle.

Metode: Jenis penelitian ini merupakan penelitian kualitatif dengan pendekatan studi kasus. Penelitian dilaksanakan di Kota Surakarta, Jawa Tengah, pada bulan September 2018 sampai dengan Maret 2019. Pengambilan data dilakukan melalui wawancara mendalam dan analisis dokumen. Teknik pengambilan sampel dengan criterion sampling. Informan penelitian berjumlah lima orang yang merupakan unsur pimpinan Pemerintah Kota Surakarta dan 10 orang yang berasal dari masyarakat Kota Surakarta. Validitas data dilakukan dengan triangulasi, member check, dan peer debriefing.

Hasil: Implementasi kebijakan JKN di Kota Surakarta hingga mencapai UHC dipengaruhi oleh: aktor yang berkomitmen tinggi serta memiliki kompetensi dalam menyukseskan program JKN, proses yang dinamis dalam menyesuaikan kebijakan pusat ke daerah dengan menerapkan berbagai strategi dan inovasi untuk meningkatkan cakupan kepesertaan JKN, adanya konteks berupa faktor politik dengan pembuatan kebijakan yang mendukung tercapainya UHC, faktor lingkungan di mana kepadatan penduduk di Kota Surakarta merupakan yang terpadat di Jawa Tengah, adanya kesadaran dan kemauan yang tinggi dari masyarakat Kota Surakarta untuk memiliki JKN, serta dukungan teknologi yang mempermudah koordinasi dan pelaksanaan JKN.

Kesimpulan: Pencapaian UHC di Kota Surakarta merupakan hasil dari optimalisasi keempat faktor dalam policy analysis triangle.

\section{INTRODUCTION}

Universal Health Coverage (UHC) is a global health priority and is one of the main elements in the Sustainable Development Goals (SDGs) established by the United Nations in September 2015. ${ }^{1}$ The main objective of UHC is to ensure that all people can access good quality of health services without causing financial difficulties. ${ }^{1,2}$ The target towards UHC in Indonesia began in 2014 with the launch of a national social health insurance scheme through the Jaminan Kesehatan Nasional (JKN) program which aims to provide health insurance for all Indonesians.
The JKN program is implemented by the Badan Penyelenggara Jaminan Sosial (BPJS) Kesehatan. ${ }^{3}$

In early 2018, four provinces in Indonesia have reached UHC, namely Aceh, DKI Jakarta, Gorontalo, and West Papua. ${ }^{4,5}$ Central Java Province have committed to reach the UHC early following the four provinces that have already reached UHC. As of August 2018, there are only three cities/ regencies that have won UHC, one of which is Surakarta City. ${ }^{5}$ Surakarta City is the third city government in Central Java after Semarang City and Demak Regency can reach UHC. Percentage the coverage of JKN participation in Surakarta City in July 2018 was $95.54 \%$ which fulfilled the coverage to achieve UHC which was $95 \%{ }^{6}$

The achievement of UHC in Surakarta City which is earlier than the target is a good learning that might be replicated elsewhere. According to Minh et al (2014), the existence of strong policies both at national and regional levels can accelerate the achievement of UHC among ASEAN countries. ${ }^{7}$ This is consistent with Iyer et al (2018) research that one of the drivers of UHC achievement is the existence of policies and strong politics. ${ }^{8}$ Walt and Gilson (1994) developed a policy analysis triangle for analyzing policies, where policies can be influenced by actors, content, processes and contexts. ${ }^{9}$ This study aims to explore more deeply the involvement of actors, processes and contexts in which to effect on the achievement of UHC in Surakarta City.

\section{METHODS}

This is a qualitative study with a case study design. The research was conducted from September 2018 to March 2019 in Surakarta City, Central Java. Data collection was carried out through in-depth interviews and document analysis. In-depth interviews with informants were conducted to understand social phenomena from the perspective of participants. Sampling technique with criterion sampling.

Data obtained from policymakers and implementers were confirmed through in-depth interviews with the community. The number 
of informants in this study is fifteen people.. Five informants came from the leadership elements of the Surakarta City Government, Department of Population and Civil Registration, Social Department, Health Department and BPJS Kesehatan and the other informants are from the Surakarta City (community). Five informants were members of JKN funded by the local government called "penerima bantuan iuran" or PBI, three informants are JKN members with independent financing, and two informants do not have health insurance. The sample criteria included informants knowing the intricacies of the JKN problem in the Surakarta City, informants were those who carried out JKN optimization activities in Surakarta, informants were officials in the Surakarta City environment so that informants had knowledge in practice and at the policy level taken and were competent in providing explanation and opinion about the object of research namely Universal Health Coverage in Surakarta City. Data validity was done by triangulation, member check, and peer debriefing.

\section{Ethical Clearance}

This study received ethical permission from the Ethics Committee, DrMoewardi Surakarta Hospital. The researcher also asked for approval from the informant before conducting in-depth interviews, including asking permission to record the interview process both video recordings and sound recordings. The informant's identity was kept confidential.

\section{RESULTS}

Based on the results of in-depth interviews and document analysis, the involvement of actors, processes and contexts in influencing the achievement of Universal Health Coverage content in Surakarta City is as follows:

\section{Actor}

Surakarta City Government, Department of Population and Civil Registration, Social Department, Health Department and BPJS Kesehatan branch Surakarta have a role in JKN policy to be able to reach UHC in Surakarta City. The Surakarta City Government has a role in synergizing all the agencies associated with JKN to be able to carry out their duties and roles to the fullest. The City Government will also oversee the implementation of JKN starting from the planning, implementation and control stages so that the implementation of the JKN program can run optimally and the people of Surakarta City can be protected by comprehensive health insurance. JKN journey in Surakarta City was inseparable from the strong commitment of the Surakarta City government in supporting JKN policies and achieving UHC in Surakarta City.

"Related to UHC here, indeed the commitment from the city government is extraordinary. The commitment of the regional leaders in this case the Mayor did prioritize service. This was reflected in the mission of the city government where health services became the first mission in the Surakarta city government.

\section{"(Informant 1)}

The government's commitment is reflected in the first mission of the Surakarta City government namely "Waras". One form of embodiment of the mission is to have health insurance for all Surakarta people. To realize comprehensive health insurance or UHC for the people of Surakarta City, the city government issues policies that support the implementation of health insurance in Surakarta.

Department of Population and Civil Registration has a major role in verifying data related to population data so that the data on the number of residents in Surakarta City becomes valid. Social Department has a role in verifying data on the poor and vulnerable to social risks in Surakarta City.

"If it is appropriate [duty and function] in the field of empowerment of the poor, it has a role to ensure that poor people and residents are vulnerable to social risk in Surakarta City, get social protection or health insurance or not." (Informant 3)

The Health Department is responsible for serving JKN registration applications for residents who do not have health insurance 
that meets the requirements. When there are people who do not yet have health insurance, both poor and vulnerable people can apply for JKN registration by bringing the conditions set by the Health Department. Furthermore, the Health Department will verify the submissions from residents. For residents who meet the requirements, the Health Department will integrate into BPJS Kesehatan for the issuance of JKN cards.

"[The Health Office] integrates from this the proposal from residents to seek health insurance. We don't have to serve our people as well as we can, as well as those who seek our health insurance, they are in the health department. "(Informant 4)

The role of BPJS Kesehatan is following what was stipulated in law number 24 of 2011 concerning the social security organizing body in article 10 . The article states that the duties of the BPJS Kesehatan include conducting and or receiving registration of participants, collecting and collecting contributions from participants and employers, receiving contribution assistance from the government, managing social security funds for the benefit of participants, collecting and managing data on participants in social security programs, paying benefits and financing health services under social security programs, providing information on administering social security programs to participants and the community.

In carrying out its role, each agency coordinates and collaborates between sectors for the optimal implementation of JKN and to support the achievement of UHC in Surakarta City.

"Here in the case of UHC, there is coordination between Department of Population and Civil Registration [Disdukcapil] then BPJS Health, Social Service and also Health Service" (Informant 2)

Coordination between sectors in the Surakarta City Government and the BPJS Kesehatan related to this JKN policy has been very well established. Coordination is done through WhatsApp, regular meetings, andthrough monitoring and evaluation. Through this coordination, various issues related to JKN in Surakarta City will be discussed to find problems, as well as solutions. Information related to participation will also be discussed at the meeting. So that all parties can find out the progress of the JKN program in Surakarta City. By knowing their respective roles and responsibilities in supporting JKN and the existence of good coordination between agencies, they able to encourage the achievement of UHC in Surakarta City.

\section{Context}

The context behind the achievement of UHC in Surakarta City covers political, environmental, technological factors, and human resource Political Factors

Political factors that play a role in driving UHC achievement include regional health insurance policies for poor-people, poverty reduction policies, UHC socialization policies, and budget availability. Those political factors include health insurance policies for near-poor people, poverty reduction policy, UHC socialization policy and budget availability.

The mayor of Surakarta regulation number $21 \mathrm{~A}$ in 2017 concerning regional health insurance for near-poor people states that everyone has the right to the highest degree of health, one of which is the existence of health insurance. With the existence of this regulation, the health insurance covered by the Surakarta City Government is not only limited to the poor but also includes the near-poor. So that the coverage of JKN participation funded by the Surakarta City Budget can increase.

The poverty reduction policies in Surakarta city are regulated in mayor regulation No. 11 of 2016 concerning the procedure for the establishment and working procedures of urban poverty alleviation teams in Surakarta City. The government regulates the establishment of the poverty reduction coordination team (Tim Koordinasi Penanggulangan Kemiskinan/ TKPK) and the kelurahan poverty reduction team (Tim Penanggulangan Kemiskinan Kelurahan/ TPKK), which functioned as a cross-sectoral and cross- 
stakeholder coordination forum that served as a forum for coordination and implementing poverty reduction policies and programs in kelurahan.

Circular letter number 440/571 of 2018 concerning UHC instructs the leaders of companies/ BUMN /BUMD/ Private, head of sub-district and village head of Surakarta city and all Surakarta city community to become JKN participants to realize UHC in Surakarta City. This circular letter is one form of JKN socialization from the city government to all elements of Surakarta City so that all parties can know the importance of participating in JKN so that the coverage of JKN participation in Surakarta City can increase. This circular letter are for people who cannot afford to immediately register with the Kelurahan in accordance with the terms and conditions, for people are able to immediately register as JKN participants at an independent cost, for people who work in BUMN/ BUMD/ large, medium and small businesses to coordinate with leaders to register as JKN participants andfor employers to immediately register their employees as JKN participants.

"The strategy is with officers, circulars [the mayor's circular letter about UHC] with socialization." (Informant 4)

Budget is needed in JKN premium financing. The Surakarta city government has allocated budgets originating from the Surakarta city regional budget or $A P B D$ to finance the premium payment of PBI APBD participants in the city of
Surakarta. The budget is regulated in regional regulation number 11 of 2017 concerning the regional health system listed in chapter VI concerning health financing in article 55 which states that the regional government allocates a budget for health at least $10 \%$ of the APBD after deducting salary expenditure. The budget for premium payments for residents who are included in the PBI APBD Surakarta City category is also not limited in the amount of the budget as long as the residents fulfil the requirements to become PBI participants, the premium will be paid for by the Surakarta city budget. Based on the health profile of Surakarta City in 2017, the Surakara city government's health budget for 2017 reaches $10.95 \%$. With the availability of regional budgets to pay for JKN premiums, the scope of participation in the PBI APBD category will increase.

"If you meet the requirements, it will be printed. Placed and financed by the city government. "(Informant 4)

\section{Environmental factor}

The population density of Surakarta city is quite high, reaching 12,802 people $/ \mathrm{km}^{2}$, which is the most densely populated in Central Java. The highest population density is in Pasar Kliwon sub-district, which is 17,882 people $/ \mathrm{km}^{2}$. While the average population density in the province of Central Java is 1,053 people $/ \mathrm{km}^{2}$. The following is a table of population density figures per subdistrict in Surakarta city:

Table 1. The population density in Surakarta city per district in 2018

\begin{tabular}{|c|c|c|c|c|}
\hline \multirow{2}{*}{ District } & \multicolumn{2}{|c|}{ Total population } & \multirow{2}{*}{$\begin{array}{c}\text { Area } \\
\left(\mathrm{km}^{2}\right)\end{array}$} & \multirow{2}{*}{$\begin{array}{c}\text { Population } \\
\text { density }\end{array}$} \\
\hline & $\mathbf{N}$ & $\%$ & & \\
\hline Laweyan & 100,664 & 17.85 & 8,64 & 11,650 \\
\hline Serengan & 53,643 & 9.51 & 3,19 & 16,815 \\
\hline Pasar Kliwon & 86,144 & 15.28 & 4,82 & 17,872 \\
\hline Jebres & 144,551 & 25.64 & 12,58 & 11,490 \\
\hline Banjarsari & 178,812 & 31.71 & 14,81 & 12,073 \\
\hline Total & 563,814 & 100 & 44,04 & 12,802 \\
\hline
\end{tabular}

Source: aggregate data of the Population and Civil Registration Department of Surakarta city in Semester 1 of 2018 
A high population density impact on the quality of occupancy that can affect the health status of the people of Surakarta City. So that UHC is a mandatory thing to improve public health. With the presence of UHC, it is expected to be able to reduce problems related to population density which includes the degree of health and productivity of the community.

\section{Technology Factors}

The existence of an integrated application system can facilitate the population data collection process and coordination between agencies. Some systems are used such as the Electronic Welfare Information System (E-SIK), Next Generation Social Welfare Information System (SIKS-NG) and Population Administration Information System (SIAK). In the Surakarta city government, the three systems have been implemented optimally and strongly support the data collection program for both population data collection and the data collection for the poor. With this application, information exchange between institutions related to JKN is faster. So that JKN data collection in Surakarta city can run smoothly. The data held by each institution in Surakarta city has good synchronization. The main data related to population data in Surakarta city, between institutions have the same data. So, there is no data bias from the institutions.

The Surakarta city government also applies information disclosure to all communities. Every policy from the city government can be accessed by the public online through the internet and broadcast on municipal television. Online access to city government policies through the jdih. surakarta.go.id website. The programs carried out by the Surakarta city government were also broadcast on city-owned television, namely Batik TV. The Surakarta city government also launched the "Solo Destination" application which can be accessed online by downloading the application in the play store. In this application, there are various features regarding the city of Surakarta. With the openness information in the Surakarta city government, the Surakarta community became easily aware of the programs, policies and information relating to public services implemented by the city government.

\section{Human Resources Factors}

Human resources involved in optimizing the JKN program are human resources within the Surakarta city government and human resources from the people of Surakarta city. UHC in Surakarta city is the main objective of the JKN program in Surakarta city, so all human resources within the Surakarta city government are actively involved in achieving that goal. All employees contribute to realizing the first mission, which makes sense. The contribution of each employee varies according to the duties and authority of each organization in which there are references in supporting the implementation of JKN in Surakarta city to realize UHC. The active role of each employee is also indicated by the picket schedule on holidays, to be able to continue serving JKN participants. So that with the picket schedule outside the working day, reporting the validity of population data will always be updated.

The next is the Surakarta city community itself. The achievement of UHC in Surakarta City is inseparable from Surakarta's high public awareness of JKN. Public awareness is caused by people's understanding of the importance of health insurance. The public's understanding of the importance of JKN was also explained by informants from the elements of the Surakarta city community. According to the informant, health insurance is needed because the arrival of illness cannot be predicted, the condition of the illness itself will require a lot of money to get health services. By having health insurance, the community will be calmer and do not need to be confused when they need medical expenses because they have been covered by JKN. Also, some people have an awareness that by becoming a member of JKN, he participates in reducing the burden of others who are sick, because JKN insurance is a mutual cooperation, in which healthy people will help cover medical expenses for people who are sick. (Summary of the results of interviews with informants 
from the people of Surakarta City is presented in Table 2).

"Furthermore, here also pay attention to the awareness of the community and awareness of registering as JKN KIS participants in the appropriate segment. When viewed from the present percentage of participation, the level of awareness of the people of [Surakarta] itself is also high. "(Informant 5)

"[I participated in JKN] just in case if at any time sick, I am not confused about thinking about the costs." (Community 3)

"In my opinion, health insurance is necessary, because the sick condition is an unpredictable condition and sometimes it costs a lot of money in the family, so the insurance is alleviating." (Community 9)

"Yes, I want it to come for social too, not just for just in case if at any time sick, that's not so." (Community 5)

Table 2. Summary of interview results with Surakarta city community

\begin{tabular}{|c|c|c|c|}
\hline Informant & $\begin{array}{c}\text { Health } \\
\text { insurance }\end{array}$ & $\begin{array}{c}\text { The reason for joining JKN and not } \\
\text { joining JKN }\end{array}$ & $\begin{array}{c}\text { Information source about } \\
\text { JKN }\end{array}$ \\
\hline Community 1 & $\begin{array}{l}\text { Independent } \\
\text { JKN }\end{array}$ & $\begin{array}{l}\text { Because of sickness and lodging in the } \\
\text { hospital so it needs relief fees }\end{array}$ & neighbour \\
\hline Community 2 & JKN PBI & $\begin{array}{l}\text { Feeling the need to have JKN just in } \\
\text { case when sick so that they apply to } \\
\text { become JKN PBI participants. }\end{array}$ & $\begin{array}{l}\text { socialization of citizens' } \\
\text { meetings, neighbourhood } \\
\text { association }\end{array}$ \\
\hline Community 3 & JKN PBI & $\begin{array}{l}\text { Feeling the need to have JKN just in } \\
\text { case when sick so that they apply to } \\
\text { become JKN PBI participants. }\end{array}$ & $\begin{array}{l}\text { socialization of citizens' } \\
\text { meetings, neighbourhood } \\
\text { association }\end{array}$ \\
\hline Community 4 & JKN PBI & $\begin{array}{l}\text { Feeling the need to have JKN just in } \\
\text { case when sick so that they apply to } \\
\text { become JKN PBI participants. }\end{array}$ & $\begin{array}{l}\text { socialization of citizens' } \\
\text { meetings, neighbourhood } \\
\text { association }\end{array}$ \\
\hline Community 5 & $\begin{array}{l}\text { Independent } \\
\text { JKN }\end{array}$ & Social reasons to help people in need & $\begin{array}{l}\text { pamphlets, leaflets, and } \\
\text { socialization from bpjs } \\
\text { kesehatan }\end{array}$ \\
\hline Community 6 & JKN PBI & $\begin{array}{l}\text { Feeling the need to have JKN just in case } \\
\text { when sick so that they apply to become } \\
\text { JKN PBI participants to Kelurahan. }\end{array}$ & $\begin{array}{l}\text { socialization of citizens' } \\
\text { meetings, neighbourhood } \\
\text { association }\end{array}$ \\
\hline Community 7 & $\begin{array}{l}\text { Independent } \\
\text { JKN }\end{array}$ & $\begin{array}{l}\text { Feeling the need to have JKN just in } \\
\text { case when sick so register to become } \\
\text { a class } 3 \text { JKN participant }\end{array}$ & $\begin{array}{l}\text { socialization from } \\
\text { puskesmas, socialization } \\
\text { of citizens' meetings, } \\
\text { neighbourhood association }\end{array}$ \\
\hline Community 8 & JKN PBI & $\begin{array}{l}\text { Feeling inadequate so proposed to } \\
\text { become a JKN PBI participant }\end{array}$ & $\begin{array}{l}\text { socialization from a } \\
\text { neighbourhood association }\end{array}$ \\
\hline Community 9 & $\begin{array}{l}\text { Do not have } \\
\text { Insurance }\end{array}$ & $\begin{array}{l}\text { Have not had time to register but intend } \\
\text { to register after taking care of the new } \\
\text { family cards. }\end{array}$ & $\begin{array}{l}\text { television, socialization } \\
\text { from puskesmas }\end{array}$ \\
\hline Community 10 & $\begin{array}{l}\text { Do not have } \\
\text { Insurance }\end{array}$ & $\begin{array}{l}\text { Know that having JKN is important but } \\
\text { lazy to register because the process is } \\
\text { complicated and long }\end{array}$ & friends, family \\
\hline
\end{tabular}

Based on Table 2, the average understanding and awareness of the Surakarta city community towards JKN has been very good. JKN PBI participants have an awareness that they have a low economic level, where to pay for the daily lives they already have difficulties, especially when added to expenses that must be paid when a family member is sick. Knowing 
the benefits of the JKN program, the poor and inadequate people have the awareness to register themselves through Kelurahan to become JKN PBI participants. Citizens who are also able to have a good awareness of the importance of this health insurance program, which can relieve financing when falling ill. Besides that, being a JKN participant is also a form of mutual cooperation by helping to ease the burden of other participants who are falling ill. With a good understanding of JKN, public awareness of the importance of participation in JKN has increased, so that the coverage of JKN participation in Surakarta city is high.

\section{Process}

The process of implementing JKN policy in the city of Surakarta was accompanied by many process dynamics. Health insurance journey in Surakarta city began with the "Pemeliharaan Masyarakat Kota Surakarta" (PKMS). PKMS is further regulated in mayor regulation number 26 of 2013.

"That is the health insurance in Surakarta City, which is the first PKMS card. There are 2 PKMS cards namely Silver and Gold."(Informant 4)

The type of PKMS card consists of "Gold" which includes the poor who are registered in the mayor's decree regarding the determination of the poor but have not been accommodated in the central government community health insurance called Jamkesmas program. The poor who have not yet entered the mayor's decision can submit a Gold PKMS type with a certificate from the Kelurahan and endorsed by the citylevel verification team, while the "Silver" PKMS participants are all people who register as PKMS participants.

Furthermore, with the existence of mayor regulation number 37 in 2016, PKMS was changed to "Bantuan Kesehatan Masyarakat Kota Surakarta" (BKMKS). The BKMS program is a change in form of the PKMS silver category which was removed because of the regulation on a single health insurance system, JKN. In contrast to PKMS Gold who later automatically became a JKN participant, PKMS Silver, which did not belong to the poor and very poor families, turned to become BKMKS. BKMKS is assistance for the community who are not able and not guaranteed with national health insurance as a form of responsibility from the local government in providing services to the community.

"Then after that, it was changed to BKMKS.

The BKMKS with the 37th anniversary of 2016. BKMKS was assistance. So if there are people who are sick at the hospital, they will get assistance in the amount of Rp. 5,000,000.

\section{"(Informant 4)}

The PKMS Silver change to become BKMKS itself not under direction of the participation roadmap towards UHC, where all maps of the regional health insurance participants (Jamkesda) must be registered as JKN participants by the end of 2016. So Jamkesda, namely BKMKS should have been integrated and merged into JKN. BKMKS itself is assistance from the city government with the highest number of treatment claims borne by Rp. 5.000.000. The reality shows that this assistance has not been effective enough in helping residents. This is because there are still many disadvantaged citizens who are burdened with the number of maintenance costs. Residents are not able to be a concern by the Surakarta government, because if people didn't get enough attention, it is feared that it will fall into the category of poor. The concern of the city government is the issuance of the mayor's regulation No. 21.A in 2017 concerning Regional Health Insurance for the Poor, which includes the BKMKS integration policy to JKN.

In January 2018, a total of 4.693 participants were successfully integrated into JKN and increased rapidly in February with 41.105 BKMS participants integrated into JKN. The coverage of JKN's participation, especially in the APBD financing sector, is increasing rapidly. As of July 2018, the integration of JKN increased by 23.273 participants so that the total number of participants covered by the Surakarta regional budget reached 119.661 people or $21.26 \%$. The total coverage of JKN participation in Surakarta city on July 2018, as 
many as 547.726 people or $95.54 \%$ of Surakarta residents have been protected by JKN. So that as of July 2018, Surakarta city has reached UHC where the coverage of JKN participation is more than $95 \%$. For the community financed by the provincial government budget as much as 1.704 people $(0.3 \%)$, financed by the national budget as much 159288 people (28.30\%) and who pay independently as much as 257.073 people (45.68\%).

\section{Strategies to increase JKN coverage in Surakarta city}

The Surakarta City Government and Surakarta branch of BPJS Kesehatan launched several strategies to increase JKN coverage in Surakarta city which include overall socialization and increase data validity. The socialization program related to JKN and UHC was carried out thoroughly by all parties related to optimizing the implementation of the JKN program. The socialization was carried out by actively plunging into the community through meetings by inviting village administrators to be briefed on JKN to later be delivered to their respective residents. Also, all regional organizations are obliged to answer questions from the public regarding JKN.

"We will socialize this issue at the beginning of

21.A in 2017, so the procedure for submitting

invited citizens is the management RT RW.

Let the RT RW be the citizens to get KIS PBI

health insurance funded by the Surakarta city

government. "(Informant 4)

Socialization is also through cultural approaches such as through "wayang" and "ketoprak" where the topics presented are related to health insurance. Socialization was also carried out through cadres and institutions through routine citizen meetings, community leaders and the village community empowerment institution. Socialization was also held by the Puskesmas both directly and through family visit programs. Direct socialization to the community has good results in increasing community knowledge about JKN. This was evidenced by the people of Surakarta city who knew and understood the importance of JKN after getting direct counselling from several parties.

"[I know JKN] there is counselling from the $R T R W$ [neighbourhood association] when there are community meetings. There is also counselling from the puskesmas, but if it is notified from the RT RW (Community 7)

BPJS Kesehatan also innovates by forming JKN cadres and UHC teams to optimize socialization, education, a membership registration, reminder and collection collections and service information providers. BPJS Kesehatan also conducts direct socialization at the Solo car-free day event. The existence of this stand makes it easier for the public to access information related to JKN because of socialization regarding the registration mechanism, payment of contributions and others. The socialization of the JKN program was also carried out through electronic media through broadcasts on local media such as TATV and Batik Surakarta Television. Information relating to JKN was also conveyed in a broadcast on radio by the Mayor of Surakarta. Socialization was also delivered through print media in the form of billboards, running text, posters, leaflets, banners, banners.

Surakarta City people get a lot of information through this media. According to the community, with the dissemination of electronic media such as through television and socialization through print media through pamphlets and leaflets on JKN in many places, he became aware of the benefits of the JKN program, so people were interested in registering as JKN participants.

"I know [JKN] from announcements, pamphlets from the Surakarta government. I work in a school, now there it is. Besides that, when I went to the hospital there was also a flyer. (Community 5)

UHC is closely related to data validity, where to achieve UHC, population related data must be valid and up to date. The Surakarta City Government has several programs to update population data. The first program was updating the data on deaths carried out through the "Besuk Kiamat" program. The "Besuk Kiamat" program or condolence for sending a death certificate is one of the innovations of The Population and Civil 
Registration Department to update population administration data. In this program, Surakarta people who die will immediately issue their death certificates within $1 \times 24$ hours. So that the people who died were no longer in the family cards. Regarding JKN, with the rapid reporting of death data, the data on JKN participants who died will be immediately known so that the deceased participant has not been billed for payment.

JKN also relates to poor population data because it is related to financing in the contribution recipient sector or PBI. Therefore, updating poor population data is very important. To maintain the validity of the data of the poor, the Surakarta city Government issued a Mayor Regulation No. 11 of 2016 concerning the procedures for the establishment and working procedures of urban poverty alleviation teams in Surakarta city. In the pilot, it regulated the establishment of the TKPK and the TPKK which one of its main tasks was to manage and update data and profiles of poor families in Surakarta city.

The third program is updating JKN membership data in Surakarta city in the Health Department to be sent to all sub-districts by name by address. Kelurahan can see the membership data in each sub-district. So that each lurah can find out residents who already have JKN, as well as those who do not have JKN.

The Surakarta city government also adopted a strategy to maintain UHC. The strategy is carried out by giving BPJS E-Id for newborns from JKN PBI participants. E-Id is valid for three months. So that it is expected that within a span of three months, the family can already exchange E-Id with a JKN card. E-Id itself can be used by newborns to get health services in health facilities.

"Including thatyesterday there was a dynamic that the new policy of BPJS did not provide claims for newborns. Solo, immediately, the policy of every baby born in Solo, residents of Solo have been given protection from the Regional Budget. (Informant 1)

The administration of E-Id by the Surakarta City government was realized in an integrated birth certificate service program named "Sapukuwat". The government also launched a transfer program for independent participants who defaulted on paying premiums JKN became a participant in the APBD PBI. The Surakarta city government issued the policy to help alleviate the economy of the people so they would not fall into the poor.

Table 3. Increase in JKN participation coverage in Surakarta city

\begin{tabular}{lcccccc}
\hline \multicolumn{1}{c}{ Month } & $\begin{array}{c}\text { Total } \\
\text { population }\end{array}$ & $\begin{array}{c}\text { PBI } \\
\text { APBN }\end{array}$ & $\begin{array}{c}\text { PBI } \\
\text { APBD }\end{array}$ & $\begin{array}{c}\text { non- } \\
\text { PBI }\end{array}$ & $\begin{array}{c}\text { Number of JKN } \\
\text { participants }\end{array}$ & $\begin{array}{c}\text { Percentage of } \\
\text { participants }\end{array}$ \\
\hline July 2018 & 562,801 & 159,288 & 121,365 & 257,073 & 537,726 & $95.54 \%$ \\
August 2018 & 562,801 & 159,002 & 124,887 & 258,055 & 541,944 & $96.29 \%$ \\
January 2019 & 563,814 & 161,352 & 130,821 & 261,337 & 553,510 & $98.17 \%$ \\
\hline
\end{tabular}

Source: BPJS Kesehatan branch Surakarta, 2018b; Surakarta City Health Department, 2018.

Based on Table 3, the coverage of JKN participation in Surakarta city has increased every month. In January 2019, the achievement of JKN membership reached $98.17 \%$ of the total population of Surakarta city. This is inseparable from the various strategies implemented by all parties involved in optimizing the JKN program. With the innovations being implemented, it is expected that Surakarta city can increase membership achievements so that $100 \%$ of the people of Surakarta city can be protected by national health insurance.

\section{DISCUSSION}

In analyzing a policy, there is a policy analysis triangle developed by Walt and Gilson. The model of policy analysis triangle is used to understand the various factors involved in each policy process. The policy analysis triangle emphasizes the main role of the actor and the relationship 
between the actor and the three other factors that influence decision making which includes context, content and process. ${ }^{10}$

Actors are actors of policy. ${ }^{11}$ The Surakarta city government has a role in synergizing all departments, namely the Population and Civil Registration Department, the Social Department, the Health Department and the BPJS Kesehatan, to carry out their duties and roles optimally. The government will oversee the planning, implementation, and control of JKN policies. The Surakarta city government has a strong commitment to achieving UHC. The government can adjust policies from the centre so that it can be implemented properly in Surakarta by making appropriate policies to optimize the implementation of the JKN program. The Surakarta city government has implemented a role under Supriyantoro's research (2014) that the implementation of the JKN program must be balanced with the provision of a space for flexibility for regions to participate in the decision-making process dynamically. ${ }^{12}$

In carrying out its role, each agency in the Surakarta city government has coordinated and cooperated well. Achievement of the UHC requires partnerships and collaboration between institutions. ${ }^{13}$ Also, to achieve UHC coordination is needed at both the national and district/ city levels. ${ }^{14}$ By knowing their respective roles and responsibilities in supporting JKN and the existence of good coordination between agencies able to encourage achievement of UHC in Surakarta City.

The process of implementing the JKN policy in the city of Surakarta runs dynamically. The city government has experienced a delay in adjusting the central policy of integrating the Jamkesda into JKN. This policy is following the direction of the roadmap to participation towards universal health insurance where on the map to UHC there should no longer be Jamkesda. Jamkesda should have been integrated and merged into JKN before 2017. However, the last city government managed to catch up with issuing mayor regulation number 21.A in 2017 which included BKMKS integration policy which is regional health insurance in Surakarta city into JKN. With the existence of this policy, the process of implementing policies in the city of Surakarta became harmonized with the central JKN policy, and the coverage of JKN's participation in the APBD's financing sector increased rapidly. Integrating local budget allocations for direct payment of health insurance into JKN can accelerate the achievement of UHC. ${ }^{14}$ As of July 2018, JKN integration has increased by 23.273 participants so that the total participants paid for the premium by the Surakarta regional budget reached $119.661 .^{6}$

The coverage of JKN membership in Surakarta city continued to increase with the various strategies carried out by all parties involved. With the comprehensive socialization, it has an impact on increasing JKN membership. The Surakara city community became aware of the importance of the JKN program. This is deal with Roesalya et al (2014) research that the existence of socialization can increase JKN membership coverage. ${ }^{15}$ Furthermore, through apocalypse innovation, update poverty data and JKN membership data, the validity of data in Surakarta city government is guaranteed. Valid data availability is one of the factors that can drive the achievement of UHC. ${ }^{8,16}$ The Surakarta City Government also implemented a strategy to maintain UHC by providing BPJS E-Id for newborns from JKN PBI participants and the program of transferring independent participants late in paying contributions to $\mathrm{PBI}$ participants for maintain UHC in Surakarta City.

Context represents the environment or situation in which the policy process occurs. ${ }^{10}$ According to Pisani et al (2017), UHC in Indonesia is largely determined by political factors. ${ }^{17} \mathrm{JKN}$ journey in Surakarta city is inseparable from the strong commitment of Surakarta city government to support JKN policies and UHC achievement in Surakarta City. This is consistent with the research conducted by lyer et al (2018) and Minh et al (2014) that one of the factors driving UHC achievement is the existence of strong political and policy commitments. ${ }^{7,8}$ This is realized by the issuance of various policies that support the 
implementation of health insurance in Surakarta.

The existence of budget allocation for JKN premium payments in Surakarta City is also one form of city government policy to achieve UHC. In terms of maintaining the budget, political commitment is needed so that health coverage increases and health services become evenly distributed. ${ }^{7}$ The next context is the high population density of Surakarta city which reaches 12.802 people $/ \mathrm{km}^{2}$, which is the most densely populated in Central Java. According to Christiani et al (2014) that population density will affect the degree of public health so that a strategy is needed in the form of health insurance to improve the quality of life. ${ }^{18}$ So that UHC becomes a mandatory thing to improve community health status.

Technological factors also influence the achievement of UHC in Surakarta city. With the existence of an integrated and optimal application system and good data synchronization between institutions can simplify the population data collection process and coordination between agencies. The data is up to date and accurate which will make it easier for the government to make policies to succeed UHC. ${ }^{19}$ Also, by implementing information disclosure, Surakarta people are easily aware of the programs, policies and information regarding public services implemented by the city government. The fourth context concerning human resource factors where UHC in Surakarta City is the main objective of the JKN program implementation in Surakarta City, so that all human resources, especially in Surakarta City government, are involved in achieving that goal. The involvement and coordination of all human resources can support the JKN's success. ${ }^{14}$ Each regional apparatus organization is involved based on their respective roles and tasks aimed at the success of UHC in Surakarta city. The achievement of UHC in Surakarta city is also inseparable from the high awareness of Surakarta people towards JKN. The perception and public awareness of the benefits of the JKN program can increase the coverage of JKN participation.

There are several limitations to these studies.
In this study, researchers analyzed of the scope of JKN membership, especially in the sector of Penerima Bantuan Iuran (PBI). The researcher has not delved deeply into the scope of JKN participation in the non-PBI sector. Quality dimensions of UHC have not been explored in depth by the researchers. Researchers did not conduct focus group discussions (FGD) in data collection. Primary data in the study used indepth interviews, so there is a possibility of recall bias, which has been minimized by researchers with validation with document analysis and media review. Despite the limitation of this studies, we hope that results of this study are expected to contribute new theories about the involvement of actors, content, processes and contexts in influencing the implementation of JKN, as well as the factors that drive UHC achievement. This research is also expected to provide input and contribution, especially for other districts/ cities that have the same characteristics so that the target towards UHC in Indonesia can be realized soon.

\section{CONCLUSION}

The success of Surakarta city applying the JKN policy to achieve UHC is inseparable from the interrelationship of all components in the policy analysis triangle. Actors who carry out their respective roles optimally and have the flexibility to adjust the process to the existing context to provide support in achieving content so that it can be achieved optimally. In each policy process, the four factors of the policy analysis triangle will be interrelated and influence each other. The existence of a strong commitment to guarantee protection for the community, making data based on valid data, implementing strategies and innovating JKN optimization, as well as the involvement and good coordination between institutions are the keys to the success of Surakarta City reaching UHC.

\section{CONFLICT OF INTEREST}

No conflict of interest 


\section{Acknowledgement}

We would like to thank the Master of Family Medicine Study Program, Sebelas Maret University, thank you for your support during the research.

\section{REFERENCES}

1. World Health Organization. Tracking Universal Health Coverage - First Global Monitoring Report. 2015;1-86.

2. Organization WH. Ministerial Roundtable: Sustainable Development Goals ( SDGs ) and Universal Health Coverage ( UHC ). 2016;(September).

3. BPJS Kesehatan. Jaminan Kesehatan Sudah Di Depan Mata. Januari. 2018;

4. Bappenas. Indonesian health sector review. Jakarta: bappenas; 2014.

5. Dinkes Papua Barat. Menjadi yang Ke Empat di Indonesia: UHC Papua Barat [Internet]. p. 2018. Available from: https://dinkespapuabarat.wordpress.com/2018/03/03/ menjadi-yang-ke-empat-di-indonesia-uhcpapua-barat/

6. Dinas kesehatan Surakarta. Laporan peserta BPJS Kesehatan bulan Desember 2018. Dinas kesehatan Surakarta; 2018.

7. Minh VH, Pocock NS, Chaiyakunapruk N, Chorvann, Duc HA, Hanvoravongchai P, Lim J, Prisno PE, Nawi N, Phaholyothin N, Phonvisay A, Soe KM S V. Asean integration and its health implication: Progress toward universal health coverage in ASEAN. Global Health Action [Internet]. 7:25856. Available from: https://www. tandfonline.com/doi/pdf/10.3402/gha. v7.25856\%40zgha20.2015.8.issue-s3

8. Iyer HS, Chukwuma A, Mugunga JC, Manzi A, Ndayizigiye M, Anand S. A comparison of health achievements in Rwanda and Burundi. Health and Human Rights. 2018;20(1):199-211.

9. Walt G, Gilson L. Reforming the health sector in developing countries: The central role of policy analysis. Health Policy and Planning. 1994;9(4):353-70.

10. Lehmann U. Understanding and Analyzing Health Policy. Modul Guide. School of Pub- lic Health: University of the Western Cape. South Africa: School of Public Health: University of the Western Cape.; 2016.

11. Massie R. Kebijakan Kesehatan: Proses, Implementasi, Analisis Dan Penelitian. Buletin Penelitian Sistem Kesehatan. 2012;12(4).

12. Supriyantoro. Formulasi Kebijakan Integrasi Jaminan Kesehatan Daerah Ke Sistem Jaminan Kesehatan Nasional Menuju Universal Health Coverage Ringkasan. 2014;62.

13. Ota MOC, Kirigia DG, Asamoah-Odei E, Drameh-Avognon PS, Olu O, Malecela MN, et al. Proceedings of the first African Health Forum: Effective partnerships and intersectoral collaborations are critical for attainment of Universal Health Coverage in Africa. BMC Proceedings. 2018;12.

14. Agustina R, Dartanto T, Sitompul R, Susiloretni KA, Suparmi, Achadi EL, et al. Universal health coverage in Indonesia: concept, progress, and challenges. The Lancet. 2019;393(10166):75-102.

15. Roesalya P. Hubungan Terpaan Sosialisasi Bpjs Kesehatan Dan Sikap Masyarakat Pada Program Dengan Keputusan Masyarakat. 2014;

16. Rukmini R, Ristrini R, Tumaji T. Integrasi Jamkesda dalam JKN bagi PBI di Kota Blitar dan Kota Malang. Buletin Penelitian Sistem Kesehatan. 2017;20(1).

17. Pisani E, Kok MO, Nugroho K. Indonesia's road to universal health coverage: A political journey. Health Policy and Planning. 2017;32(2):267-76.

18. Christiani C, Tedjo P, Martono B. Analisis Dampak Kepadatan Penduduk Terhadap Kualitas Hidup Masyarakat Provinsi Jawa Tengah. Jurnal Ilmiah Untag Semarang [Internet]. 2014;102-14.

19. Obare V, Brolan CE HP. Indicators for Universal Health Cobverage: can Kenya comply with the proposed post 2015 monitoring recommendations?. International Journal for Equity in Health,. 2014;13:123. 